\title{
A pedagogização do discurso do consumo no processo de escolarização
}

IGNÁCIO, Patrícia ${ }^{1}$

\section{RESUMO}

O presente artigo investiga o processo de pedagogização do discurso do consumo nas práticas discursivas escolares, dando ênfase às condições de possibilidade para a materialidade do referido discurso no processo de escolarização e à forma como ele opera na produção dos sujeitos escolares para o consumo. Para dar visibilidade à pedagogização do discurso do consumo, a pesquisa compõe uma estratégia analítica inspirada nas proposições de Michel Foucault acerca da análise do discurso e da governamentalidade; nos Estudos Culturais; e nas descrições feitas por autores tais como Bauman, Schor, Lipovetsky, Sarlo, entre outros, sobre a condição humana em tempos marcados pela cultura de consumo. O corpus de análise é composto por textos enunciadores do discurso do consumo no processo de escolarização, retirados das Diretrizes Curriculares Nacionais, dos Parâmetros Curriculares Nacionais, de livros paradidáticos, dos manuais de formação de professores e de Planos do Portal do Professor/MEC. Os resultados apontam para: (1) um quadro de conceitos, objetos e modalidades que reverberam e materializam o discurso do consumo no campo da educação e (2) um conjunto de tecnologias de si - inscritas na rede de sistemas de significações da sociedade de consumo - por meio das quais os sujeitos se observam, se interpretam, se julgam, se narram, se gerenciam e se moldam. Tais dados mostram a forma como as práticas discursivas escolares pedagogizam o discurso do consumo - de acordo com o regime de verdade de campo discursivo da educação -, ensinando os sujeitos escolares a desempenhar o papel de consumidores.

Educação e Consumo. Educação para o Consumo. Escola e Consumo. Processo de Escolarização e Consumo.

\section{The pedagogical transformation of consumption discourse in the schooling process}

\section{ABSTRACT}

\footnotetext{
${ }^{1}$ Doutora em Educação pela Universidade Federal de Pernambuco. Professora Adjunta da Universidade Federal do Rio Grande (FURG), atuando nos cursos Licenciatura em Ciências Exatas. Licenciatura em Pedagogia EAD e no Curso de Pós-Graduação em Ensino de Ciências Exatas. Email: patriciaignacio.furg@gmail.com. Lattes: http://lattes.cnpq.br/3042180832996423. ORCID: https://orcid.org/0000-0003-2145-2957.
} 
This paper investigates the process of pedagogization of consumption discourse in school discursive practices, emphasizing the conditions of possibility for the materiality of this discourse in the schooling process and the way it operates in the production of school subjects for consumption. To give visibility to the pedagogization of consumer discourse, the research composes an analytical strategy inspired by Michel Foucault's propositions about discourse analysis and governmentality; in Cultural Studies; and in the descriptions made by authors such as Bauman, Schor, Lipovetsky, Sarlo, among others, about the human condition in times marked by consumer culture. The corpus of analysis consists of texts that enunciate the discourse of consumption in the schooling process, taken from the National Curriculum Guidelines, National Curriculum Parameters, paradidmatic books, teacher training manuals and Teacher Portal / MEC Plans. The results point to: (1) a framework of concepts, objects and modalities that reverberate and materialize the discourse of consumption in the field of education and (2) a set of self technologies - inscribed in the network of meaning systems of the consumer society. - through which subjects observe, interpret, judge, narrate, manage and shape themselves. These data show how school discursive practices pedagogize consumer discourse - according to the discursive field truth regime of education - by teaching school subjects to play the role of consumers.

\author{
Education and Consumption. Consumer Education. School and \\ Consumption. Schooling Process and Consumption.
}

\title{
Il discorso sul consumo ne la formazione Scientífica
}

\section{RIASSUNTO}

Questo documento cerca di indagare il discorso sul consumo nelle pratiche nelle scuole, sottolineando le condizioni de la materialità del discorso nel processo scolastico e il modo in cui opera nella produzione di materie scolastiche per il consumo. Per dare visibilità alla al discorso del consumatore, la ricerca compone una strategia analitica ispirata alle proposizioni di Michel Foucault sull'analisi del discorso e sulla governabilità; in studi culturali; e nelle descrizioni fatte da autori come Bauman, Schor, Lipovetsky, Sarlo, tra gli altri, sulla condizione umana in tempi segnati dalla cultura del consumo. II corpus di analisi è costituito da testi che enunciano il discorso del consumo nel processo scolastico, tratti da Linee guida per i curricula nazionali, parametri dei curricula nazionali, libri paradidmatici, manuali di formazione degli insegnanti e piani del portale / MEC per gli insegnanti. I risultati indicano: (1) un quadro di concetti, oggetti e modalità che riverberano e materializzano il discorso del consumo nel campo dell'educazione e (2) un insieme di auto-tecnologie - inscritte nella rete di sistemi di significato della società dei consumi. - attraverso cui i soggetti osservano, interpretano, giudicano, narrano, gestiscono e modellano se stessi. Questi dati mostrano come le pratiche discorsive scolastiche pedagogano il discorso dei consumatori - secondo il regime discorsivo della verità sul campo

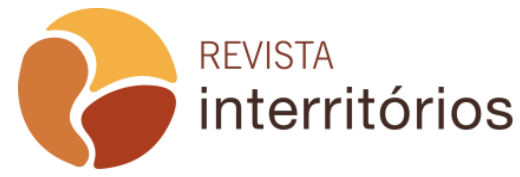


dell'educazione - insegnando alle materie scolastiche a svolgere il ruolo dei consumatori.

Istruzione e Consumo. Educazione Al Consumo. Scuola e Consumo. Processo Scolastico e di Consumo.

\section{La transformación pedagógica del discurso del consumo en el proceso escolar}

\section{RESUMEN}

Este artículo investiga el proceso de pedagogización del discurso del consumo en las prácticas discursivas escolares, enfatizando las condiciones de posibilidad para la materialidad de este discurso en el proceso escolar y la forma en que opera en la producción de asignaturas escolares para el consumo. Para dar visibilidad a la pedagogización del discurso del consumidor, la investigación compone una estrategia analítica inspirada en las proposiciones de Michel Foucault sobre el análisis del discurso y la gubernamentalidad; en estudios culturales; y en las descripciones hechas por autores como Bauman, Schor, Lipovetsky, Sarlo, entre otros, sobre la condición humana en tiempos marcados por la cultura del consumidor. El corpus de análisis consiste en textos que enuncian el discurso del consumo en el proceso escolar, tomados de las Pautas del Currículo Nacional, Parámetros del Currículo Nacional, libros paradidmáticos, manuales de capacitación docente y Planes del Portal del Maestro / MEC. Los resultados apuntan a: (1) un marco de conceptos, objetos y modalidades que reverberan y materializan el discurso del consumo en el campo de la educación y (2) un conjunto de auto tecnologías inscritas en la red de sistemas de significado de la sociedad de consumo a través del cual los sujetos se observan, interpretan, juzgan, narran, gestionan y modelan. Estos datos muestran cómo las prácticas discursivas escolares pedagogizan el discurso del consumidor, de acuerdo con el régimen de educación discursiva de campo de la verdad, al enseñar a los sujetos escolares a desempeñar el papel de consumidores.

Educación y consumo. Educación del consumidor. Escuela y consumo. Proceso de escolarización y consumo.

\section{INTRODUÇÃO}

Os estudos sobre a forte presença do consumo no espaço da escola têm sido recorrentes em diferentes áreas do conhecimento ${ }^{2}$. Tais estudos têm

\footnotetext{
${ }^{2}$ Seja no campo da Sociologia, da Psicologia, da Comunicação Social, seja no campo da Educação, autores como Juliet B. Schor (2009), Naomi Klein (2009), Marisa Vorraber Costa (2009), Mariangela Momo (2007) e Momo e Costa (2009), entre outros tem dado visibilidade a
} 
chamado a atenção para a forma como o consumo vem adentrando os muros e interferindo na rotina da escola. Isso porque já há um consenso entre tais pesquisadores de que o consumo constitui-se em uma importante ferramenta para a condição humana contemporânea.

No Brasil, além das investigações já mencionadas, a infiltração, o entrosamento e a articulação do consumo no campo da educação têm sido pauta recorrente em um número significativo de pesquisas. Incomodados, seja com a forma como crianças e jovens buscam assemelhar seus comportamentos e vestuários aos dos personagens em destaque na mídia ${ }^{3}$; seja com o modo como o consumo interage com o currículo escolar, reproduzindo práticas de uma sociedade em que o mesmo se mostra em evidência; ${ }^{4}$ pesquisadores buscam problematizar a forma como a presença do consumo no espaço da escola tem dado o "tom" na rotina escolar de crianças e jovens. Filiado a esse grupo de estudos que articulam ferramentas do campo da educação e o consumo, a intenção deste artigo - resultado dos estudos desenvolvidos em tese de doutoramento - é colocar em discussão a forma como o discurso do consumo se materializa, articula, transita e vem sendo pedagogizado pelo campo da educação, na contemporaneidade, por meio de práticas discursivas escolares, capazes de capturar, orientar, determinar, modelar e governar os sujeitos escolares para o consumo.

Para esse intento, realizou-se a coleta de textos educacionais sobre 0 consumo, materializados no processo de escolarização, e estabeleceram-se filiações com os Estudos Culturais, com os Estudos acerca do Consumo e com as teorizações de Michel Foucault. De tal entrecruzamento, emergiu a compreensão de que o consumo, em tempos presentes, se constitui em um discurso que opera no campo da educação, estabelecendo uma grade de inteligibilidade acerca da forma adequada de consumir, promovendo a racionalidade 5 dos sujeitos escolares para a sociedade de consumo.

Dentre os diversos elementos que compõem 0 processo de escolarização, elegeu-se para a análise - devido à recorrência, à importante ação formadora, à capilaridade e ao status - as Diretrizes curriculares nacionais gerais da educação básica (BRASIL, 2013); os Parâmetros curriculares nacionais: introdução aos parâmetros curriculares nacionais (BRASIL, 1997); Livros Paradidáticos; Planos de Aula sobre o consumo, publicados no Portal do

forma como o consumo tem transitado e constituído formas de ser e conviver no espaço-tempo da escola.

${ }^{3}$ Vide Ignácio (2007), Flor (2007).

${ }^{4}$ Vide Valença (2000), Momo (2007), Araújo (2008).

${ }^{5}$ Segundo Avelino (2010, p. 146), Foucault entendia por racionalidades "[...] os conjuntos de prescrições calculadas e razoáveis que organizam instituições, distribuem espaços e regulamentam comportamentos; nesse sentido as racionalidades induzem uma série de efetivos sobre o real." 
Professores6/MEC; e Manuais de Formação de Professores. Ao eleger esses textos como objeto de investigação do discurso do consumo nas práticas discursivas escolares, o objetivo central foi colocar em evidência e em discussão as regras do discurso do consumo e as técnicas de formação do sujeito consumidor no processo de escolarização.

Neste momento, impõe-se referir que, associado ao campo das teorizações pós-críticas do currículo, o texto apresentado não pretendeu discutir se o consumo é um conteúdo "verdadeiro" ou "falso". Ou ainda, se ele deve ou não ser incluído na matriz curricular, como uma disciplina ou como um conteúdo transversal.

Afinal não importa mais perguntar se determinada abordagem, determinado conhecimento ou conteúdo é verdadeiro ou falso. Importa saber como determinados conhecimentos vieram a ser considerados mais verdadeiros que outros. Importa saber os processos, os procedimentos, a feitura, a fabricação. Importa descrever como funciona e como veio a funcionar de determinados modos. (PARAísO, 2005, p.75).

Importa a este trabalho descrever "a feitura, a fabricação" da pedagogização do discurso do consumo no processo de escolarização e a forma como ele conseguiu se imbricar e adentrar no jogo de saber-poder do campo da educação, disputando com outros saberes os dizeres e fazeres sobre o sujeito da educação e capacitando crianças e jovens para a Sociedade de Consumo. No entanto, faz-se oportuno colocar que o discurso do consumo não é aqui pensado como o único a transitar no campo da educação, mas como pertencente a uma constelação discursos que circulam no processo de escolarização. Em outras palavras, a escola é permeada por uma constelação de discursos que conversam, dialogam, se entrecruzam, se rejeitam - entre eles os discursos do consumo, discurso multicultural, discurso tecnológicos etc.

\section{O processo de pedagogização}

Ancorado nas investigações de Yves Chevallard, Forquin (1993, p. 16) narra a pedagogização como um processo "[...] de reorganização, de reestruturação ou 'transposição didática'[...]" do conhecimento. Nesse processo, o campo da educação seleciona todos os saberes que considera

\footnotetext{
${ }^{6}$ Criado em 2008, o Portal do Professor se constitui em um ambiente virtual onde os professores podem acessar sugestões de planos de aula ou criá-los, baixar mídias de apoio, ter acesso a notícias sobre educação e iniciativas do MEC, participar de discussões ou fazer cursos, ter acesso a links diversos, entre outros. O objetivo da ferramenta é apoiar o processo de formação de professores. (BRASIL, c2010d).
}

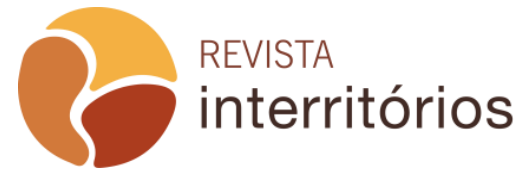


importantes em uma dada sociedade e os transforma, para que possam se tornar aptos a serem ensinados.

Para José Carlos Libâneo (2001, p.10) a pedagogização implica em uma direção pedagógica e consiste em

[...] submeter os conteúdos científicos a objetivos explícitos de cunho ético, filosófico, político, que darão uma determinada direção (intencionalidade) ao trabalho com a disciplina e a formas organizadas do ensino. Nesse sentido, converter a ciência em matéria de ensino é colocar parâmetros pedagógico-didáticos na docência da disciplina, ou seja, juntar os elementos lógico-científicos da disciplina com os políticoideológicos, éticos, psicopedagógicos e os propriamente didáticos.

O sociólogo Basil Bernstein (2003) descreve a pedagogização como a apropriação, descontextualização, transformação e recontextualização dos saberes no discurso educacional. Para o autor, esse processo de transmissão de saberes é mediado por um dispositivo de regulação de discursos e práticas. Nele, tanto os textos/saberes se submetem às regras do discurso educacional, quanto o discurso educacional se interpenetra às regras do discurso desse texto/saber.

Ao estabelecer a relação entre poder, sujeito e discurso, Michel Foucault (2010b) dá outro tom ao debate a respeito da pedagogização. Segundo o filósofo, a pedagogização envolve a transmissão de verdades, por meio de arranjos de poder discursivo ou simbólico, capazes de dotar os sujeitos de capacidades, aptidões e saberes.

Jorge Larrosa (2013), também filiado às problematizações de Bernstein e Foucault, emprega o termo pedagogização - em seu texto $A$ novela pedagógica e a pedagogização da novela - para designar a forma como a novela passou a ser pedagogizada pelo discurso educacional. Segundo o autor, o texto literário é (con)formado à estrutura do logos pedagógico, por meio de jogos do dizer, jogos de poder, jogos da verdade, para que possa transitar no campo da educação. Nesse entremear, o discurso pedagógico "[...] seleciona o texto, determina a relação legítima com o texto, controla essa relação e determina hierarquicamente 0 valor de cada uma das realizações concretas da leitura [...]" (LARROSA, 2013, p. 130).

A professora Julia Varela (2000), em consonância com as teorizações de Foucault, descreve a pedagogização como um processo de remodelação sucessiva; a transformação e reinterpretação dos saberes; e as técnicas e procedimentos de conversão do conhecimento, para controlar e organizar os saberes que serão transmitidos. Por meio desses processos, os saberes são submetidos às regras do discurso que os enunciam. Em seus estudos, Varela (2000) destaca quatro grandes procedimentos: a eliminação e desqualificação 
dos saberes considerados "pequenos"; a normalização e adaptação dos saberes uns aos outros; a classificação hierárquica dos saberes; e a centralização piramidal dos saberes.

No debate acerca das compreensões do que venha a ser o processo de pedagogização, elaborou-se a compreensão de que a pedagogização do discurso do consumo pelo processo de escolarização é a ação de reconceitualizar e recontextualizar os saberes de uma cultura, por meio das regras do discurso educacional. Ação que está fortemente implicada na transmissão de verdades, na apropriação dos saberes e na produção de sujeitos em uma dada sociedade.

\section{Caminhos teórico-metodológicos}

Para traçar um dos possíveis caminhos investigativos, a fim de compreender o processo de pedagogização do discurso do consumo nas práticas discursivas escolares e perceber como o sujeito consumidor é produzido nessas práticas, foi determinante a leitura e aproximação de trabalhos teóricos e metodológicos produzidos por Michel Foucault, ${ }^{7}$ acerca da análise do discurso e da governamentalidade, e pelos estudiosos do campo dos Estudos Culturais.

Nessa perspectiva investigativa, para mapear a pedagogização do consumo nas práticas discursivas escolares, em tal material empírico, realizou-se a análise das regras de formação "[...] (formação dos objetos, formação das posições subjetivas, formação dos conceitos e formação das escolhas estratégicas) [...]" (FOUCAULT, 2009, p. 131) do discurso do consumo no campo da educação. Além disso, analisou-se as técnicas de dominação e de si que permeiam as práticas discursivas escolares, por entender que elas dão visibilidade à forma como o processo de escolarização vem pedagogizando o discurso do consumo.

Sarfati (2010) identifica e categoriza duas abordagens de Análise do Discurso: a abordagem analítica e a abordagem integradora. $O$ teórico explica que a abordagem analítica - oriunda da teoria da ideologia de Louis Althusser - "[...] pressupõe que o discurso oferece polos de resistência, estratégias ocultas que só a análise pode trazer à luz [...]" (SARFATI, 2010, p. 119), enquanto a abordagem integradora - oriunda dos estudos de Michel Foucault

\footnotetext{
${ }^{7}$ Autores como Paul Veyne (2008), Paraíso (2012), Deleuze (1986), entre outros, compreendem que Michel Foucault, em suas investigações, estruturou métodos de análise, ao quais podemos nos aproximar para problematizar nossos objetos de pesquisa e estabelecer possíveis caminhos de investigação. Seguindo na esteira de tal compreensão, nos filiamos ao referido autor, para tentar problematizar a forma como o discurso do consumo se interpenetrou ao discurso educacional, promovendo a formação de sujeitos escolares consumidores.
}

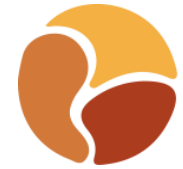


acerca da arqueologia do saber - "[...] pressupõe que um discurso é acessível à análise quando posto em relação com outros parâmetros que lhe dão sentido [...]" (SARFATI, 2010, p. 119).

Dentre as abordagens supracitadas, interessou ao estudo as teorizações desenvolvidas por Michel Foucault. Pois, o autor mostra como investigar "[...] não 'o que está por trás' dos textos e documentos, nem 'o que se queria dizer' com aquilo, mas sim descrever quais são as condições de existência de um determinado discurso, enunciado ou conjunto de enunciados [...]" (FISCHER, 2001, p. 221).

Assim sendo, Foucault (2008b, p. 7) entende que "[...] o discurso está na ordem das leis [...]" e que cabe à Análise do Discurso

[...] compreender o enunciado na estreiteza e singularidade de sua situação; de determinar as condições de sua existência, de fixar seus limites da forma mais justa, de estabelecer suas correlações com outros enunciados a que pode estar ligado, de mostrar que outras formas de enunciação exclui. Não se busca, sob o que está manifesto, a conversa semi-silenciosa de um outro discurso: deve-se mostrar por que não poderia ser outro, como exclui qualquer outro, como ocupa, no meio dos outros e relacionado a ele, um lugar que nenhum outro poderia ocupar. (FOUCAULT, 2009, p. 31).

Para tanto, o autor francês produziu e trilhou um caminho investigativo que denominou Arqueologia do saber (FOUCAULT, 2009). Segundo Foucault (2009, p. 157), o problema da arqueologia é "[...] definir os discursos em sua especificidade; mostrar em que sentido o jogo de regras que utilizam é irredutível a qualquer outro; seguir ao longo de suas arestas exteriores para melhor salientá-los [...]". Seu objetivo é definir "[...] as regras de formação de um conjunto de enunciados [...]" (FOUCAULT, 2009, p. 188), estabelecer "[...] a regularidade dos enunciados [...]" (FOUCAULT, 2009, p. 163, grifo do autor). Sua tarefa é mostrar em que condições pode haver uma correlação entre enunciados novos e acontecimentos "exteriores", e em que consiste precisamente (quais são seus limites, forma, código, lei de possibilidade) (FOUCAULT, 2009).

Ao empregar o termo discurso, Foucault se distancia de conceito, sentido oculto, análise e interpretação ou teoria. Não o compreende como significado das palavras, mas sim como "[...] práticas que formam sistematicamente os objetos de que falam [...]" (FOUCAULT, 2009, p. 55). E, se o discurso forma as coisas narradas, ele tem o poder de produzir o que diz. Entretecendo uma relação de tal perspectiva com a presente investigação, se o discurso do consumo nas práticas discursivas escolares descreve um tipo de relação dos sujeitos com o ato de consumir, ele tem o poder de produzir uma forma específica de viver em sociedade.

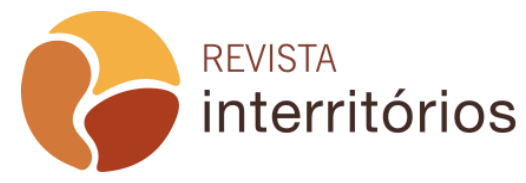


Dialogando com tal teorização, interessou ao estudo a rede conceitual de enunciados do consumo que circula em artefatos pedagógicos do ensino fundamental e que compõe a formação discursiva do consumo no campo educacional.

Para tanto, foi preciso

[...] reconstituir o sistema geral de pensamento, em cuja rede, em sua positividade, torna possível um jogo de opiniões simultâneas e aparentemente contraditórias. É essa rede que define as condições de possibilidade de um debate ou de um problema, é ela a portadora da historicidade do saber. (FOUCAULT, 2002, p. 103).

Foi necessário estabelecer as condições de possibilidade e de existência do processo de pedagogização do discurso do consumo no campo da educação em um determinado tempo e espaço, de onde emergiu uma rede de saberes capazes de fabricar sujeitos capazes de transitar na Sociedade de Consumo.

\section{A intenção foi}

[...] descrever um conjunto de enunciados para aí reencontrar não o momento ou a marca de origem, mas sim as formas específicas de um acúmulo; não é certamente revelar uma interpretação, descobrir um fundamento, liberar atos constituintes. (FOUCAULT, 2009, p. 141).

Não para descrever como as coisas são, mas para narrar como elas se constituíram. Para definir quais as regras do discurso do consumo e o seu papel na organização das relações entre os indivíduos, instituições e organizações sociais.

O panorama teórico estudado possibilitou a percepção de que há, na contemporaneidade, uma formação discursiva do consumo (vários enunciados circulantes e coexistentes) que transita nas práticas discursivas escolares. Há um certo número de enunciados que apresentam semelhança na dispersão e regularidade de objetos, de tipos de enunciação, conceitos e de escolhas temáticas (FOUCAULT, 2009), que caracterizam a formação discursiva do consumo no discurso educacional.

Conforme explica o Foucault, os enunciados seguem um conjunto de regras anônimas, históricas e contingentes, denominadas práticas discursivas, que autorizam o que e de que forma as coisas podem ser ditas ou não (FOUCAULT, 2009). Há um campo de condições de existência produzido dentro de uma sociedade que controla, seleciona, organiza e redistribui a produção do discurso, por meio de "[...] procedimentos que têm por função conjurar seus poderes e perigos, dominar seu acontecimento aleatório,

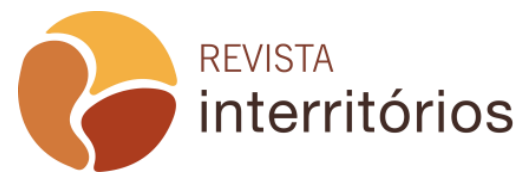


esquivar sua pesada e temível materialidade [...]" (FOUCAULT, 2008b, p. 9). Materialidade somente constituída em um determinado tempo e espaço e em conformidade com uma rede conceitual de enunciados.

O que ocorre é que não se pode dizer tudo, em qualquer circunstância e a qualquer tempo. Existem regras que determinam o que é "verdadeiro" e o que é "falso". Para que o discurso do consumo adentrasse ao campo da educação e fizesse parte do discurso educacional, existiu um conjunto de condições de possibilidade e existência, em um determinado tempo e espaço, de onde emergiu tal rede de saberes. Bem como de uma família de campos de saber, com a qual dialoga para a aparição e manutenção do mesmo.

Pensando nas regras e condições de possibilidade e existência do discurso do consumo no processo de escolarização, utilizou-se, para a composição da chave de análise, categorias produzidas a partir de aproximações com a arqueologia de Michel Foucault (2008a), no que se refere às regras de formação do discurso (condição de existência e de coexistência do discurso do consumo na escolarização explicitadas em seus elementos: objetos, conceitos, estratégias e modos de enunciação), conforme quadro abaixo.

\section{Quadro 1 - Regras de formação para a pedagogização do discurso do consumo nas práticas discursivas escolares}

\begin{tabular}{|c|c|}
\hline \multicolumn{2}{|c|}{$\begin{array}{c}\text { Regras de Formação para a Pedagogização do discurso do consumo nas práticas } \\
\text { discursivas escolares }\end{array}$} \\
\hline $\begin{array}{l}\text { Regra de } \\
\text { formação dos } \\
\text { objetos }\end{array}$ & $\begin{array}{c}\text { - Os locais onde o discurso emerge } \\
\text { - Os campos discursivos aos quais se filia } \\
\text { - Os locais na vida dos sujeitos onde o discurso opera }\end{array}$ \\
\hline $\begin{array}{l}\text { Regra de } \\
\text { formação das } \\
\text { modalidades } \\
\text { enunciativas }\end{array}$ & $\begin{array}{l}\text { - A função que cada autor ocupa no discurso } \\
\text { - Os lugares institucionais que fortalecem e reverberam o discurso } \\
\text { - As posições que os sujeitos ocupam no discurso }\end{array}$ \\
\hline $\begin{array}{l}\text { Regra de } \\
\text { formação dos } \\
\text { conceitos }\end{array}$ & $\begin{array}{l}\text { - As várias formas pelas quais os enunciados se relacionam, } \\
\text { combinam ou divergem entre si } \\
\text { - A memória discursiva }\end{array}$ \\
\hline $\begin{array}{l}\text { Regra de } \\
\text { formação das } \\
\text { estratégias }\end{array}$ & $\begin{array}{l}\text { - Os temas que compõem o discurso } \\
\text { - O campo de práticas não discursivas }\end{array}$ \\
\hline
\end{tabular}

Fonte: Dados da Pesquisa.

Para a composição do modelo analítico que buscou dar evidência às relações de poder que agem na pedagogização do discurso do consumo nas práticas discursivas escolares, produzindo sujeitos escolares consumistas,

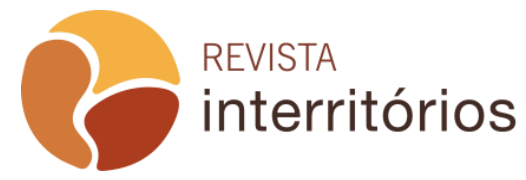


estabeleceram-se aproximações com algumas das técnicas analisadas por Larrosa (2008), no processo de escolarização, e apresentadas no texto Tecnologias do eu e educação (Quadro 2). São elas: avaliação de si, narrativa de si, rememoração de si e julgamento de si.

Quadro 2 - Tecnologias escolares de si

\begin{tabular}{|c|c|}
\hline \multicolumn{2}{|c|}{ Tecnologias escolares acionadas na Pedagogização do Discurso do Consumo } \\
\hline Rememoração de si & Relembrar-se de experiências de consumo. \\
\hline Avaliação de si & $\begin{array}{c}\text { Ver-se a partir de mecanismos ópticos oferecidos pelas práticas } \\
\text { discursivas escolares. }\end{array}$ \\
\hline Narrativa de si & $\begin{array}{l}\text { Narrar-se a partir de mecanismos discursivos que estabelecem o } \\
\text { que se pode dizer e como se pode dizer acerca de si. }\end{array}$ \\
\hline Julgamento de si & $\begin{array}{c}\text { Julgar-se segundo uma trama de valores e normas oferecidas pelas } \\
\text { práticas discursivas escolares. }\end{array}$ \\
\hline
\end{tabular}

Fonte: Dados da Pesquisa.

No estudo das técnicas que operam para a formação do sujeito moderno na civilização Ocidental, Foucault (2011a, p. 155) colocou em destaque "[...] os pontos em que as tecnologias de dominação dos indivíduos sobre os outros empregam procedimentos e processos por meio dos quais o indivíduo age sobre si mesmo [...]". Para o pensador francês, o sujeito é produzido por meio de procedimentos capazes de fazê-lo agir sobre si e tornar-se o que a sociedade espera dele.

Quanto às técnicas de dominação, também denominadas técnicas de poder, Michel Foucault compreende o conjunto das técnicas "[...] que determinam a conduta dos indivíduos, submetendo-os a certos fins ou à dominação, objetivando o sujeito [...]" (FOUCAULT, 1994, p. 2). Em tais métodos "[...] os indivíduos são dirigidos por outros [...]" (FOUCAULT, 2011a, p. 155).

Em relação ao estudo das técnicas de dominação e das técnicas de si no campo da educação, Larrosa (2008) tem buscado investigar as práticas pedagógicas como produtoras de pessoas e a escola como uma das "fábricas" de subjetivação (LARROSA, 2008) da sociedade contemporânea. O que 0 autor tem investigou são as formas como a escolarização produz técnicas de poder e promove técnicas de si, que modificam "[...] a experiência que os indivíduos têm de si mesmos [...]" (LARROSA, 2008, p. 37), "[...] transformando os seres humanos em sujeitos [...]" (LARROSA, 2008, p. 37) e normalizando-os de acordo com o modelo de sujeito considerado "verdadeiro", correto e adequado para as sociedades.

$\mathrm{Na}$ esteira de tal compreensão, selecionou-se como Território 
arqueológico, durante todo o período do doutoramento (anos de 2010 e 2013), textos enunciadores do discurso do consumo nas práticas discursivas escolares. Alguns artefatos do processo de escolarização que pedagogizam 0 discurso do consumo no campo da educação. Foram listados:

a) As Diretrizes Curriculares Nacionais (2013);

b) 3 Volumes dos Parâmetro Curriculares Nacionais $1^{\underline{a}}$ a $4^{\underline{a}}$ série (1997) (Quadro 3):

Quadro 3 - Parâmetros curriculares nacionais

\begin{tabular}{|c|c|}
\hline \multicolumn{2}{|c|}{ Parâmetros Curriculares Nacionais } \\
\hline Volume & Componente Curricular \\
\hline 4 & Ciências Naturais \\
\hline 9.1 & Meio Ambiente \\
\hline 9.2 & Saúde \\
\hline
\end{tabular}

Fonte: Dados da Pesquisa.

c) Dez Planos de aula, dos 66 planos publicados no site Portal do Professor, voltados para a formação do sujeito consumidor $\mathrm{e}$ direcionados ao Ensino Fundamental Inicial (Quadro 4):

Quadro 4 - Planos de aula - Portal do Professor/MEC

\begin{tabular}{|l|l|}
\hline \multicolumn{1}{|c|}{ CAMPO DE SABER } & \multicolumn{1}{c|}{ PLANO DE AULA } \\
\hline \multirow{2}{*}{$\begin{array}{l}\text { Ética e Cidadania } \\
\text { (10 aulas) }\end{array}$} & Moda e consumo infantil \\
\cline { 2 - 2 } & Consumismo infantil: características dos tempos modernos? \\
\hline \multirow{3}{*}{$\begin{array}{l}\text { Meio Ambiente } \\
\text { (40 aulas) }\end{array}$} & De onde vêm os produtos que consumimos? \\
\cline { 2 - 2 } & Abaixo o desperdício da água! \\
\cline { 2 - 2 } & Sustentabilidade no nosso cotidiano \\
\cline { 2 - 2 } & Dialogando com o lixo - Preservação do ambiente \\
\hline $\begin{array}{l}\text { Saúde } \\
\text { (11 aulas) }\end{array}$ & Comer, comer para poder crescer \\
\cline { 2 - 2 } & Saúde é o que interessa: de olho na alimentação e na atividade física! \\
\hline $\begin{array}{l}\text { Publicidade e } \\
\text { Propaganda } \\
\text { (5 aulas) }\end{array}$ & Aprendendo com a propaganda \\
\cline { 2 - 2 } & Publicidade: uma fábrica de desejos \\
\hline
\end{tabular}

Fonte: Dados da Pesquisa. 
d) A Atividade Didático-Pedagógica da Hora da Novidade;

e) Seis livros paradidáticos (Quadro 5):

Quadro 5 - Livros paradidáticos

\begin{tabular}{|l|}
\hline LIVROS PARADIDÁTICOS \\
\hline 1. Os heróis e consumo consciente \\
\hline 2. O camelo, o burro e a água \\
\hline 3. Direito do Consumidor e Publicidade Enganosa \\
\hline 4. No mundo do consumo: a administração das necessidades e dos desejos \\
\hline 5. Carlitos contra o consumo \\
\hline 6. O preço do consumo \\
\hline
\end{tabular}

Fonte: Dados da Pesquisa.

f) O livro Consumo e espaços pedagógicos (COELHO, 2002), voltado para a formação de professores.

É importante dizer que a junção de materiais advindos de diferentes superfícies de emergência ${ }^{8}$ se faz "[...] não para unificar a todos, transformando-os em uma 'coisa só'- em um só 'modelo' de texto, por exemplo -, mas para afirmar que em qualquer um deles há representações produzidas a partir de significados que circulam na cultura [...]" (WORTMANN, 2007, p. 75) para este estudo-investigação, na cultura do consumo. Eles constituem um recorte dos ditos e não ditos do consumo na escolarização, histórica e temporalmente datados.

\section{As regras de formação do discurso do consumo nas práticas dis- cursivas escolares}

Os achados da pesquisa mostraram que a pedagogização do discurso do consumo nas práticas discursivas escolares se materializou no momento em que os saberes do discurso do consumo se articularam ao discurso educacional. Tal materialidade, compôs um campo de saberes que não só representa a interpenetração de tais discursos, mas também o diálogo e intersecção com outros discursos que transitam no campo da educação. Sejam eles: o discurso ambientalista, o discurso político, o discurso jurídico, o discurso médico e o discurso publicitário.

\footnotetext{
${ }^{8}$ Foucault (2009) descreve as superfícies de emergência como os locais onde podem surgir os objetos que racionalizam um discurso. 
Objetos, conceitos e temas

A análise do corpus apontou que, os objetos, conceitos e temas que significam e ressignificam o consumo no campo da educação giram em torno: da administração dos desejos e necessidades, do shopping, da propaganda, da alimentação saudável, do direito do consumidor, de ações de compra e venda, da moda e da administração do consumo.

No entrecruzar dos campos da psicologia e da administração emergem textos que descrevem uma gramática prescritiva de racionalidade das ações sobre o consumo. A regra é categorizar os atos de consumo ou no campo das necessidades, ou no campo dos desejos, para, em uma perspectiva de consumidor consciente, analisar, classificar e racionalizar os seus atos de consumo.

O enunciado do consumo consciente, por exemplo aparece como tema central em três livros paradidáticos - Os heróis e o consumo consciente (CUNHA, 2011), O camelo, o burro e a água (MERLI, 2010), Consumo e espaços pedagógicos (COELHO, 2002) - e perpassa as discussões de quase todas as aulas estudadas. Sustentado nos campos da filosofia, da psicologia e da neurologia, a tomada de consciência acerca dos atos de consumo parece ter se transformado em um dos objetivos do discurso educacional.

A categorização da conduta do sujeito escolar consumidor consciente é tema no livro de imagem O camelo, o burro e a água (MERLI, 2010). Nele observa-se a prescrição de um conjunto de condutas a serem seguidas. No enredo, os personagens camelo e burro estabelecem relações diferentes com a água. Enquanto o camelo - adjetivação, geralmente, usada para designar pessoa trabalhadora e que armazena - reflete e economiza, o burro - palavra carregada do sentido pejorativo de pessoa sem inteligência - desperdiça e não racionaliza seus atos de consumo. Na sequência de imagens, a conduta dos personagens é oposta. Torneiras ligadas, banhos demorados, vazamentos e ações inconsequentes deixam o burro sem água. Enquanto o camelo - bom, consciente e racional - finaliza a história com água estocada.

Quanto à identidade do sujeito consumidor, o livro No mundo do consumo: a administração das necessidades e dos desejos (GARCIA, 2001, p. 18), de forma lúdica e envolvente, mostra por meio de imagem e frases ilustrativas, que "Consumir é criar uma identidade própria [...]". Na figura (figura 1), um jovem menino ilustra aos escolares como compor suas identidades e exemplifica alguns objetos, produtos, serviços e relações de consumo possíveis para tal operação. 
Figura 1 - Consumir é criar uma identidade própria

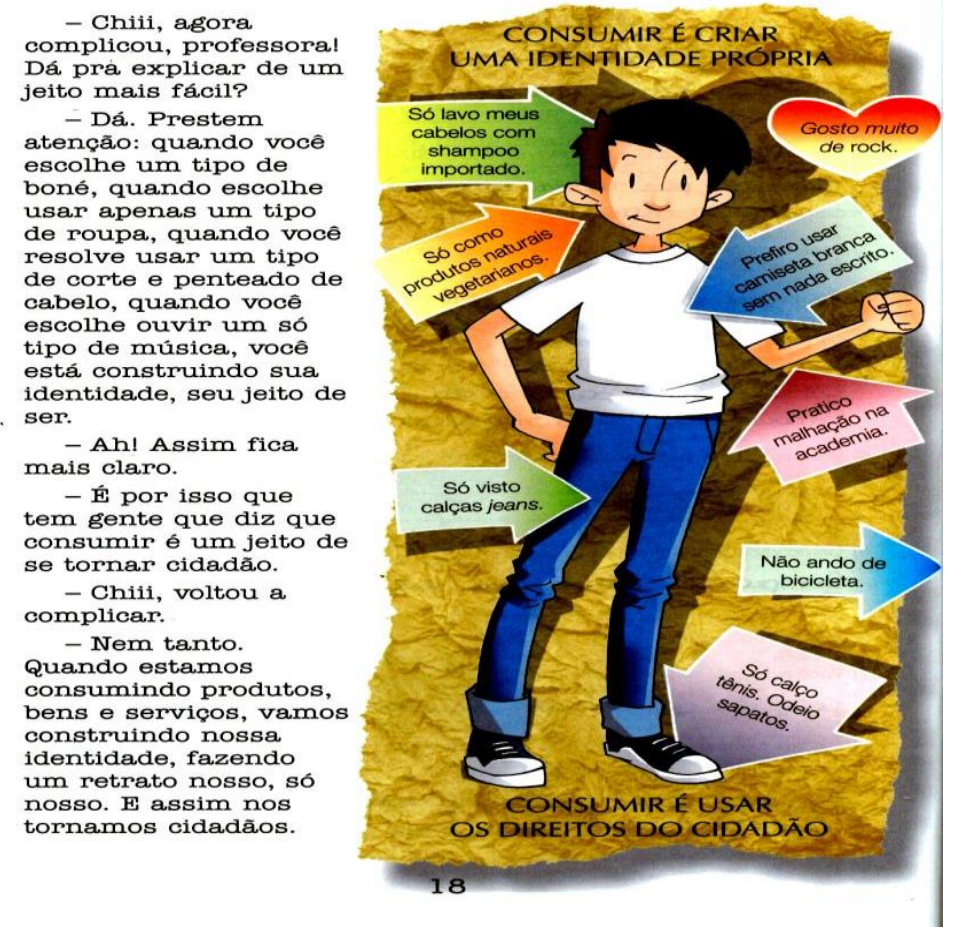

Fonte: Garcia (2001).

Ao que parece, o processo de escolarização tem ensinado crianças e jovens sobre como os objetos, produtos e serviços do consumo operam como ornamentos simbólicos (BAUMAN, 2001), como ícones identitários (SARLO, 2006), na significação de suas identidades.

Para além, o consumo também emerge como parâmetro para a compreensão do que se constitui "[...] uma vida decente [...]" (GARCIA, 2001, p. 3), uma vida com o exercício pleno da cidadania. Nos textos, viver sem dinheiro, sem comprar, sem consumir é não ter condições de exercer a sua cidadania (Ibid.). Isso porque, "[...] saber consumir é saber ser cidadão [...]" (PERNAMBUCO, 2010, p. 24).

Em sua obra Consumidores e Cidadãos, Canclini (2006, p. 59) afirma que o consumo também "[...] serve para pensar [...]". Para o autor, todas as ações dos sujeitos em sociedade externam um posicionamento político e muitas das reivindicações dos cidadãos - práticas sociais e culturais que estabelecem um sistema de significação acerca de pertencimento e identidade e de satisfação das necessidades que promovam uma certa qualidade de vida e bem-estar - são oferecidas e/ou balizadas pelo consumo. Nessa perspectiva de cidadania, o comportamento dos consumidores não se constitui de forma irracional. Ele corresponde a um conjunto de processos socioculturais, realizado por meio da apropriação e uso dos produtos (CANCLINI, 2006).

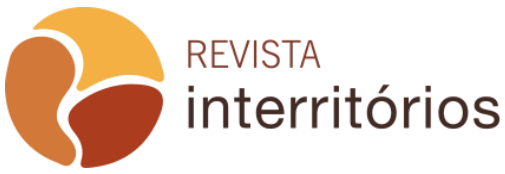


Do campo da economia e do direito percebe-se a emergência de uma gramática voltada para a capacitação dos sujeitos em relação aos procedimentos do consumo. Compra, cheque, troca, promoção, produto, cliente, saldo, dívida, juros, nota fiscal, cartão de crédito, pagamento, entre outros, são palavras que compõem a gramática discursiva do consumo na escolarização. Bons exemplos podem ser vistos na cartilha Direito do consumidor e publicidade enganosa: a escolha certa, brincando e aprendendo a ser um consumidor legal (PERNAMBUCO, 2010).

Do entretecer dos campos da moda, da propaganda, da administração e da ética vemos a preocupação com o controle e administração dos desejos. Seus temas estão voltados para a orientação dos alunos sobre propaganda, moda, publicidade, consumismo, produtos e serviços de consumo, espaços de veiculação da comunicação e tecnologias de captura dos desejos - planos Aprendendo com a propaganda, Publicidade: uma fábrica de desejos, Moda e consumo infantil.

A preocupação com o meio ambiente perpassa as discussões da metade dos livros analisados e de quatro dos dez planos em estudo. Com o foco recorrente na manutenção e preservação do planeta, o discurso do consumo no processo de escolarização evoca como práticas de significação 0 desperdício, a reciclagem, os recursos naturais, a sustentabilidade, a água, a preservação, entre outros - planos Abaixo o desperdício da água!, Sustentabilidade no nosso cotidiano e Dialogando com o lixo - preservação do ambiente.

Em se tratando da conduta ética dos sujeitos, os livros Carlitos contra $O$ consumo (TAVARES, 2011) e O preço do consumo (JAF; PALMA, 2008) colocam em evidência e em discussão os parâmetros de conduta limites para a aquisição do que se deseja. Em ambos os enredos, a luta dos personagens está em superar os desejos de consumo produzidos pelo encantador, envolvente e alucinante campo do marketing e da propaganda e entender que as relações afetivas são mais importantes do que qualquer produto, serviço ou objeto consumido. Nessa luta, as dúvidas sobre a importância do ser humano são tão grandes, que equiparam as pessoas às mercadorias (BAUMAN, 2008) e fortalecem a ideia de que o consumo é capaz de produzir bem-estar e felicidade (LIPOVETSKY, 2007).

Importante que se diga que, o conjunto dos enunciados que autorizam a aparição do discurso do consumo no processo de pedagogização estabelecem procedimentos de intervenção tais como técnicas de reescrita, métodos de transcrição e sistematização de proposições. Quanto às técnicas de intervenção, o que se vê é a retomada, a recontextualização e a reformulação dos conceitos de diferentes campos de saber para a formação do sujeito cidadão consumidor consciente. Nesses procedimentos, o discurso do consumo entra nas regras do campo da educação, dialoga com a sua gramática, é recontextu-

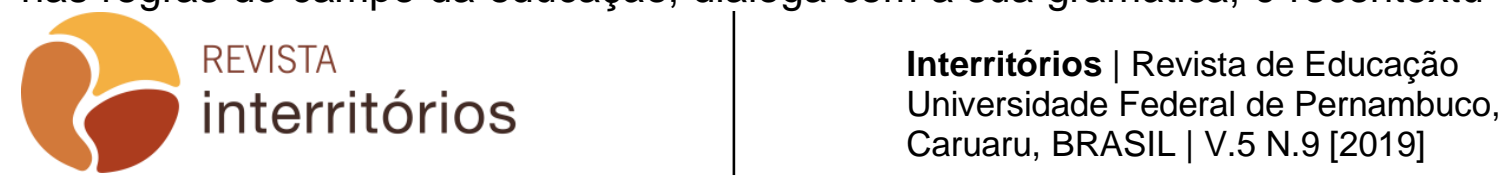


alizado e adaptado ao campo educacional e se entrecruza com outros discursos que nele transitam. Em outras palavras, tarefas como assistir a um vídeo, desenhar o que aprenderam, realizar tarefas de casa, "releitura" da atividade do "amigo-secreto" são ações da escolarização que se entrecruzam, delimitam e alinham à emergência do discurso do consumo nas práticas discursivas escolares.

\section{Os sujeitos escolares na mira do discurso do consumo}

Em um movimento voltado para o governo da conduta dos sujeitos escolares, as grades de especificação acionadas pelo discurso do consumo no processo de escolarização são os corpos, a vida social e afetiva, a conduta, o comportamento e a alma dos estudantes.

Quanto aos corpos, os enunciados presentes nos Planos de Aula Moda e consumo infantil, Comer, comer para poder crescer, Sustentabilidade no nosso cotidiano, De onde vêm os produtos que consumimos?, Saúde é o que interessa: de olho na alimentação e na atividade física e nos livros No mundo do consumo: a administração das necessidades e dos desejos (GARCIA, 2001), $O$ preço do consumo (JAF; PALMA, 2008), Consumo e espaços pedagógicos (COELHO, 2002), Direito do consumidor e publicidade enganosa: a escolha certa, brincando e aprendendo a ser um consumidor legal (PERNAMBUCO, 2010) fazem referência às relações entre corpo e consumo. Neles, os objetos, serviços e produtos do consumo parecem estabelecer formas/regras por meio das quais crianças e jovens compõem suas identidades.

Aos objetos, serviços e produtos do consumo cabe outorgar um quadro de valores e normativas, capaz de promover espaço e notoriedade nas relações sociais. Desejosos por inserção, participação e ascensão na vida social e afetiva, os sujeitos escolares são instruídos a compor, com o auxílio dos artefatos do consumo, uma identidade atraente e vendável (BAUMAN, 2008). Pois, eles aprendem e são estimulados a avaliar suas relações sociais por meio dos serviços e produtos do consumo.

Com o intuito de normalizar uma forma de consumir, o processo de escolarização estabelece prescrições e técnicas voltadas para a ação sobre a conduta e o comportamento dos sujeitos escolares. Como exemplo cita-se o flashback de Kátia, apresentado no livro No mundo do consumo: a administração das necessidades e dos desejos (GARCIA, 2001), onde a vida de Kátia é rememorada e escrutinada, a partir de atos de consumo. 
Figura 2 - Flashback do consumo

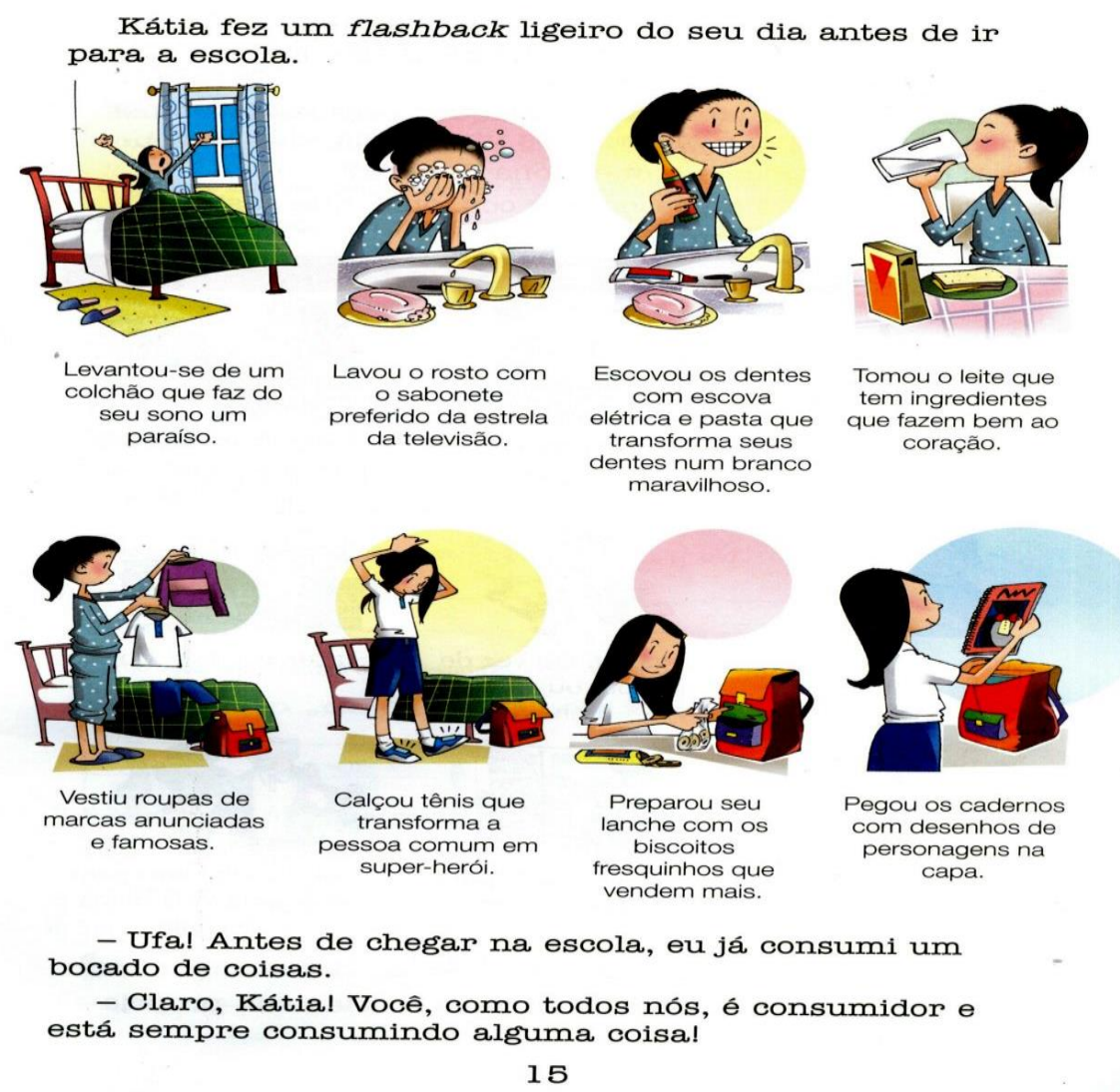

Fonte: Garcia (2001).

As modalidades enunciativas do discurso do consumo no processo de escolarização

No processo de pedagogização do discurso do consumo os sujeitos do discurso ocupam lugares diferentes e diversos. Quem fala e estabelece as regras do discurso são os especialistas do campo da educação, os pesquisadores do currículo e do planejamento, os educadores e os autores de livros paradidáticos. Enfim, profissionais com expertise (ROSE, 1998) designados a eleger e elencar os saberes ensinados, a investigar as formas possíveis de ensino e aprendizagem, a "[...] observar os alunos e as relações entre eles [...]" (AROEIRA; SOARES; MENDES, 1996, p. 137), a "coordenar as ações coletivas" (AROEIRA; SOARES; MENDES, 1996, p. 138), a estruturar as relações e a convivência e a estipular as regras de funcionamento da vida dos sujeitos escolares.

Os profissionais da educação, geralmente, recorrem ao Ministério da Educação, à mídia, aos livros paradidáticos, aos shoppings centers, aos sites 
especializados, ao Ministério Público e à Promotoria do Consumidor para acessar o discurso do consumo.

Com poder, respeitabilidade, status e capilaridade na distribuição dos discursos do campo da educação, o Ministério da Educação é um órgão federal responsável pela regulação e supervisão das instituições de ensino brasileiras. Tal instituição, ao estruturar suas ações, autoriza certos grupos de especialistas e os saberes por eles selecionados, ao mesmo tempo em que desautoriza outros. Nessa posição de saber-poder, ao inserir o consumo em sua política curricular, ele produz um regime de verdade que movimenta uma gama de pesquisas, leis, planos, entre outros, capazes de fazê-lo circular e fortalecê-lo como discurso do campo da educação.

A mídia (internet, televisão, jornais, rádio) - com capilaridade, disseminação e veiculação capaz de atingir milhões de pessoas - é considerada um veículo de produção, transmissão e recepção dos discursos em destaque na sociedade. Com um repertório que se associa a diferentes campos de saber, ela tem o poder de difundir e dispersar, de forma lúdica e prazerosa, um grande número de informações, instruindo e ensinando aos sujeitos formas de ser e conviver em sociedade.

Considerados por Sarlo (2006, p. 18) como "[...] monumentos de um novo civismo [...]" e nomeados por McLaren (1997, p. 45) como as "[...] catedrais do capitalismo [...]", os shoppings centers são aqui analisados como lugares institucionais do discurso do consumo, porque neles todas as ações, narrativas, imagens, espaços, estruturas, seduzem, interpelam, capturam, ensinam, subjetivam e governam os sujeitos para o consumo.

Com o objetivo de despertar o prazer pela leitura, de instruir e de formar cidadãos consumidores, os profissionais do campo da educação, geralmente, recorrem ao lúdico e fascinante recurso dos livros paradidáticos. Tal recurso considerado pelo campo dos Estudos Culturais como pedagógico - tem poder de disseminação, captura e encanto dos leitores escolares, o que the dá status perante outros tipos de leitura.

A relação entre o discurso do consumo e a educação também encontra sustentação nos sites especializados em temáticas que se entrecruzam com 0 mesmo. Divulgados com facilidade, pelo acesso à Internet, eles oferecem inúmeros recursos midiáticos para envolver os usuários e colocar em circulação o seu conteúdo. Um exemplo significativo são os recursos e links didáticos sugeridos nas aulas veiculadas no Portal do Professor/MEC.

Fortalecido pela filiação a instituições legais, o discurso do consumo se materializa, é pedagogizado e se dissipa, também, no Ministério Público e nas Promotorias de Defesa do Consumidor. Tais instituições, responsáveis por estabelecer a ordem jurídica para a defesa e manutenção da democracia e dos interesses sociais e individuais, têm também trabalhado na divulgação de in- 
formações que capacitem o cidadão para exercício da cidadania a partir do consumo.

$\mathrm{Na}$ posição de sujeitos aprendizes, em formação e necessitando de condução, estão os estudantes. Aos alunos cabe narrar, avaliar e julgar, suas vidas, suas almas, suas experiências de consumo - através dos critérios normativos estabelecidos na pedagogização do discurso do consumo - a um sujeito autorizado a lhes (re)conduzir para o saber escolarizado. Nessa perspectiva, o aluno é quem fala, se expõe, se exterioriza e é escrutinado, regulado, ordenado e normalizado em relação ao consumo.

\section{As tecnologias do discurso do consumo nas práticas discursivas escolares - a produção de sujeitos consumidores}

Ancorado nas teorizações de Foucault (2011a) e Larrosa (2008), o artigo toma a pedagogia como "[...] uma operação constitutiva, isto é, como produtora de pessoas [...]" (LARROSA, 2008, p. 37), por meio de relações de poder, articuladas em discursos e tecnologias que incitam, induzem, desviam, ampliam, limitam, coagem, balizam as ações dos sujeitos escolares em relação ao consumo.

$\mathrm{Na}$ estruturação de tais práticas, o campo da educação acolheu a herança das práticas cristãs ${ }^{9}$ (FOUCAULT, 2011a) e estabeleceu tarefas para o sujeito escolar "[...] conhecer a si mesmo, dizer a verdade sobre si mesmo, e constituir-se como um objeto de conhecimento tanto para outras pessoas como para si mesmo [...]" (FOUCAULT, 2011a, p. 153). A partir de então, a escola passou a ser mais um espaço institucionalizado e autorizado a desenvolver e/ou recuperar o sujeito escolar consumidor.

Para o autor,

governar pessoas, no sentido geral da palavra não é um modo de forçá-las a fazer o que o governo quer; é sempre um ponto de equilíbrio, com complementaridades e conflitos entre técnicas que garantem a coerção e os processos pelos quais o sujeito é construído e modificado por ele mesmo. (FOUCAULT, 2011a, p. 153).

Em outras palavras, não se trata de forçar crianças e jovens a desenvolverem certo tipo de comportamento de consumo. Mas, de incitá-los, interpelá-los, envolvê-los, capturá-los e subjetivá-los, por meio de um conjunto lúdico, prazeroso e envolvente de tecnologias pedagógicas estruturadas para

${ }^{9}$ Segundo Foucault (2011a) o problema das tecnologias cristãs é descobrir o que está escondido no interior do sujeito. Para tanto, recorre à pratica da confissão da verdade.

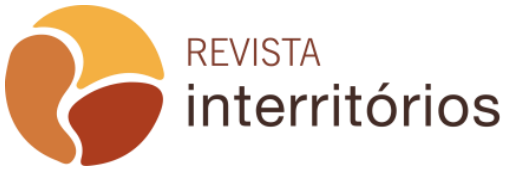


promover e/ou modificar a experiência que cada um tem de si em relação ao consumo. Tecnologias pedagógicas que funcionam como mecanismos de produção da experiência de si, no entretecer das prescrições de saber (discursos) e de ser (técnicas), promovidas e mediadas pela educação escolarizada.

Assim sendo, a escola se constitui em um dos espaços de governamento das subjetividades infantis para o consumo, por meio de "dispositivos pedagógicos [que] constroem e medeiam a relação do sujeito consigo mesmo, como se fosse uma gramática suscetível de múltiplas realizações" (LARROSA, 2008, p. 36).

No corpus analisado, evidenciaram-se movimentos que levam crianças e jovens à avaliação de si, à rememoração de si, narrativa de si, ao julgamento de si - categorias apresentadas por Larrosa (2008) em seu texto Tecnologias do eu e educação - e tomaram corpo tecnologias a que se denominou protagonização de si e gerenciamento de si em relação ao consumo.

\section{Avaliação de si}

Segundo Larrosa (2008), o homem é um ser que, ao longo dos anos, sempre se interpretou. Entretanto, o conteúdo que embasa essa interpretação é histórica, social e culturalmente contingente. Ou seja, uma vez que, ao se avaliar, o sujeito acessa um repertório, um conjunto de práticas de significação em evidência na cultura de seu tempo, que determina e constitui o que é visível dentro de si.

Nesse viés interpretativo, é possível afirmar que a concepção de sujeito consumidor, a qual as práticas discursivas escolares se propõem a normalizar, está marcada por um repertório discursivo, que compõe um conjunto de signos e significados acerca da experiência de si no contexto da Sociedade de Consumo, por meio do qual os sujeitos escolares se veem, se avaliam, se narram, se julgam, se protagonizam e se gerenciam. Dessa forma, as técnicas educacionais tomam o lugar de mediação da relação do si consigo mesmo, estabelecendo um quadro de recursos - acessado por crianças e jovens tanto para a compreensão de si, quanto para a expressão de si - para o pleno desenvolvimento de seus atos de consumo.

$\mathrm{Na}$ análise do material coletado, o que emergiu nas orientações e prescrições pedagógicas foi uma gramática discursiva voltada para a educação do consumidor, a formação do consumidor crítico e consciente, a Sociedade de Consumo, o consumo alimentar, a desigualdade de acesso aos bens de consumo, a relação entre consumo e educação ambiental e o combate ao consumo excessivo. Questões que refletem as determinações descritas nas 
Diretrizes curriculares nacionais gerais da educação básica (BRASIL, 2013) e sugeridas nos Parâmetros curriculares nacionais: introdução aos parâmetros curriculares nacionais (BRASIL, 1997) acerca da formação do sujeito escolar consumidor.

Um dos movimentos de avaliação de si propostos no processo de socialização dos atos de consumo é fazer com que crianças e jovens olhem para si e digam qual e como são as relações que estabelecem com os produtos de consumo. Para tanto, as aulas analisadas propõem que os alunos falem sobre os produtos que desejam para si e dos critérios e motivos pelos quais apresentam seus desejos de consumo (Planos: Moda e consumo infantil; Publicidade: uma fábrica de desejos) e sobre a forma como desenvolvem seus hábitos e costumes em relação ao consumo (Planos: Abaixo o desperdício da água; Publicidade: uma fábrica de desejos; Comer, comer, para poder crescer; De onde vêm os produtos que consumimos?; Sustentabilidade no nosso cotidiano).

Semelhante ao movimento promovido nos planos de aula, os livros $O$ preço do consumo (JAF; PALMA, 2008); Os heróis e o consumo consciente (CUNHA, 2011) e No mundo do consumo: a administração das necessidades e dos desejos (GARCIA, 2001) propõem uma educação do "olhar" do sujeito que se autoavalia. Neles, crianças e jovens têm acesso a enredos envolventes capazes de enquadrar e classificar os atos de consumo.

No livro No mundo do consumo: a administração das necessidades $e$ dos desejos (GARCIA, 2001), por exemplo, após entender o jogo do consumo e se fazer participante, é preciso se classificar enquanto jogador consumista ou consciente. Nesse contexto discursivo as perguntas giram em torno de: "Que tipo de consumidor você é?" (GARCIA, 2001, p. 17); "Você compra tudo o que quer?" (GARCIA, 2001, p. 17); "Como você administra a sua mesada?" (GARCIA, 2001, p. 17).

O que se percebe, nas práticas discursivas escolares, é a produção de uma identidade de consumidor específica, que passa a servir de pressuposição, critério, parâmetro para a avaliação de si e de referência para filiações na composição da identidade de crianças e jovens. Um conjunto de ações e prática de significação - permeados pelos serviços, relacionamentos, produtos e objetos oferecidos na Sociedade de Consumo e apresentados no processo de escolarização - aos quais os sujeitos se associam para avaliar-se e aprender de si.

\section{Rememoração de si}

Já a técnica de rememoração de si, instiga os estudantes a relembrar, 
dar visibilidade e trazer à tona as experiências vivenciadas em relação ao consumo, utilizando os recursos oferecidos pelas práticas discursivas escolares como ferramentas de análise e exteriorização de si.

$\mathrm{O}$ ato de revisitar os fatos e ações de consumo nas práticas escolares pode ser visto nos Planos de Aula: De onde vêm os produtos que consumimos?, Publicidade: uma fábrica de desejos, Abaixo o desperdício da água e Saúde é o que interessa: de olho na alimentação e na atividade física! e na prática pedagógica da Hora da Novidade.

A aula do Portal do Professor Publicidade: uma fábrica de desejos, por exemplo, conforme a figura 3, convida o estudante a relembrar o que 0 mobilizou a comprar, a relação que o estudante estabelece com o produto ao longo do tempo, o que aconteceu com o produto e o que ele pretende fazer com o mesmo. A proposta de trabalho consiste em estruturar as lembranças das experiências de consumo em uma tabela, para entender a história de consumo dos alunos e "começar um processo de conscientização a respeito dos hábitos consumistas que desenvolvemos sem ao menos refletir sobre eles" (BRASIL, 2009b, documento não paginado).

\title{
Figura 3 - Plano de aula - Portal do Professor/MEC 4
}

\begin{abstract}
$1^{\circ}$ momento:
Professora/or, inicie a sua aula solicitando às crianças que procurem se lembrar de um anúncio publicitário que viram na TV por esses dias. Ao ouvi-las, registre no quadro 0 nome do produto divulgado e procure saber por que o tal anúncio chamou a atenção das crianças. 0 anúncio é engraçado? É bonito? É de um produto que você quer ter? Essas perguntas poderão contribuir para a percepção dos recursos que a publicidade usa para nos influenciar na escolha dos bens materiais que ela divulga.

Em seguida, faça mais algumas perguntas: Vocês já quiseram ganhar alguma coisa porque viram um anúncio na TV, rádio, em revistas ou outro meio publicitário? Vocês conseguiram ganhar esse produto? Ainda têm esse produto com vocês? Continuam gostando dele? Usam esse produto ou ele já foi descartado? A intencão dessas perguntas é levantar um pouco da história de consumo de seus/suas alunos/as e começar um processo de conscientização a respeito dos hábitos consumistas que desenvolvemos sem ao menos refletir sobre eles.

Monte uma tabela no quadro ou em papel afixado em uma das paredes da sala, para registrar as respostas das crianças. Veja a sugestão abaixo:

\begin{tabular}{|c|c|c|c|}
\hline $\begin{array}{l}\text { Produto divulgado pela } \\
\text { publicidade }\end{array}$ & Continuam brincando com ele? & $\begin{array}{l}\text { Foi descartado, doado ou } \\
\text { abandonado? }\end{array}$ & $\begin{array}{l}0 \text { que você quer fazer com esse } \\
\text { produto? }\end{array}$ \\
\hline Uma boneca & sim & não & continuar brincando com ele \\
\hline Um carrinho de controle remoto & Nao porque ele estragou & Abandonado em cima do guarda-roupa & Mandar arrumar \\
\hline Uma sandália $X$ & Não serve mais & Está na minha sapateira & Doar para outra criança \\
\hline Um álbum de figurinhas & $\begin{array}{l}\text { Desisti de montá-lo porque as figurinhas são muito } \\
\text { caras }\end{array}$ & Está na gaveta do armário & Não sei \\
\hline
\end{tabular}

Professor/a, não é necessário que todas as crianças respondam às perguntas acima. Você determina quando parar em função do interesse da turma. Se preferir, todos deverão responder às questões como tarefa de casa e depois as respostas poderão ser exploradas por você. Em todo caso, cinco a seis respostas podem ser potencialmente proveitosas para essa aula. Explore-as como puder, por exemplo, orientando a criança que desistiu do álbum a se juntar com mais dois ou três colegas e terminar de montá-lo juntos, ou então vendê-lo, doá-lo, direcioná-lo para uma coleta seletiva de papel, ou aproveitá-lo de alguma forma criativa!

Você pode inclusive propor que organizem juntos uma a tividade de troca de produtos ou um sebo a ser realizado na escola, o que poderá ser muito estimulante e educativo. Mas, o principal objetivo da atividade descrita acima é ajudar as crianças a perceberem o quanto alguns produtos que compramos perdem logo o interesse ou são frágeis e duram menos do que se esperava ou do que 0 anúncio publicitário sugeria. Muitas vezes contribuímos para gerar mais lixo no planeta com a aquisição de tal produto. Esses são temas que se relacionam com a publicidade e o consumismo. Eles não devem ser explorados exaustivamente neste momento, mas não podem ser totalmente desconsiderados. O ideal será, após o trabalho proposto nesta aula, você direcionar suas aulas para a questão da produção de lixo e a nossa contribuição para cuidar do planeta observando os 3 Rs: Reduzir, Reutilizar, Reciclar.
\end{abstract}

Fonte: Brasil (2009b).

Para além, a título de exemplificação, citam-se as situações em que os estudantes são mobilizados a relembrarem seus hábitos de consumo de alimentos, categorizando-os como saudáveis ou não (Plano: Saúde é o que 
interessa: de olho na alimentação e na atividade física). O que ocorre é que, a partir desse movimento de relembrar, crianças e jovens passam a olhar para seus atos de consumo alimentar, analisar suas ações, categorizar seus atos e externar sua experiência de si a partir de tais categorias. Assim sendo, as experiências de consumo vividas individualmente, em família, com amigos e com colegas são retomadas, com o auxílio das "lentes" da escolarização, para que os sujeitos escolares se voltem sobre si, virem-se para trás e/ou para dentro e estabeleçam uma ação reflexiva sobre seus atos e relações com 0 consumo.

Em outras palavras, um consumidor consciente está atento, desde quando acorda, para os atos e ações de consumo e tem consciência de que os estímulos ao consumo podem não corresponder aos resultados esperados. Consciente e inteligente, o sujeito escolar recebe das práticas discursivas escolares os parâmetros que o capacitam para o exercício pleno da cidadania em uma sociedade regida para e pelo mercado.

\section{Narrativa de si}

Além de rememorarem-se e avaliarem-se, os sujeitos escolares são conduzidos a falar de seus atos e relações com o consumo, por meio do diálogo ou da escrita. A regra é falar de si e de suas experiências com o consumo, através da linguagem. Nessa tecnologia, os sujeitos são posicionados como "confessantes; não em relação a uma verdade sobre si mesmos que lhes é imposta de fora, mas em relação a uma verdade sobre si mesmos que eles mesmos devem contribuir ativamente para produzir" (LARROSA, 2008, p. 55).

$\mathrm{Na}$ "narrativa de si sobre o consumo", os sujeitos escolares acessam, através da linguagem, os conhecimentos culturais, históricos e sociais que acabam por balizar seus modos de ver-se, julgar-se e governar-se. Isso porque eles os utilizam como recurso para exteriorizar a experiência de si, para dizer aquilo que viram em seu próprio interior.

A análise do material coletado aponta para a tomada de consciência de si acerca do consumo por meio das tecnologias pedagógicas do processo de escolarização, que convocam o sujeito escolar a narrar:

Quadro 6 - Narrativas de si sobre o consumo

Quem ele é a partir do consumo

Como é viver por meio do consumo 


\begin{tabular}{|l|}
\hline A sua identidade por meio do consumo \\
\hline As suas relações afetivas a partir do consumo \\
\hline Os seus atos de consumo \\
\hline Os critérios de seus atos de consumo \\
\hline A categorização de seus atos de consumo \\
\hline A categorização do comportamento dos sujeitos com dinheiro e sem dinheiro \\
\hline As suas frustrações perante o consumo \\
\hline A relação que ele estabelece entre consumo e felicidade \\
\hline A relação que ele estabelece entre propaganda e consumo. \\
\hline
\end{tabular}

Fonte: Dados da Pesquisa.

Protagonização de si

No quadro de tecnologias pedagógicas desenvolvidas pelo processo de escolarização em relação ao consumo, identificou-se - além das técnicas selecionadas do trabalho de investigação de Larrosa (2008) - a categoria em que os estudantes podem acessar, "vivenciar", avaliar e julgar - por meio do imaginário - outras/novas formas de relação com o consumo.

$\mathrm{Na}$ tecnologia da protagonização de si, crianças e jovens são convocados - de forma lúdica, prazerosa e fascinante - a se imaginarem no lugar das personagens, para avaliar, julgar e se posicionar em relação às experiências do outro no consumo como se elas fossem suas. Além disso, os estudantes devem descrever o correto em relação às práticas do consumo, a partir dos valores e normas padrões das práticas discursivas escolares. Nessa racionalidade, há um modo correto de consumo e, ao leitor/personagem, cabe a função de reorganizar as condutas, refazer as ações desviantes ou ratificar as ações conscientes do "si personagem".

No encarte do livro O preço do consumo (JAF; PALMA, 2008), por exemplo, a proposta é assumir o lugar da personagem Joana e decidir se ela (eu) deve (devo) ou não convencer a avó a entrar em uma mala de viagem, durante a novela em que é atriz, para ganhar muito dinheiro em merchandising. A decisão é difícil. A avó da personagem tem um trauma de infância. Quando criança, enquanto atuava como contorcionista, seu parceiro de cena morreu e ela ficou presa em uma mala por um bom tempo. Durante a trama, a jovem Joana é seduzida pelos inúmeros produtos e serviços do consumo que podem ser adquiridos com o dinheiro e, por isso, tenta convencer a avó de todas as 
formas. Nessa tecnologia pedagógica, o leitor é convocado a fazer parte da "cena" e a tornar-se protagonista, para opinar, decidir e descrever o que faria no lugar das personagens.

Outra proposta de "protagonização de si" apresentada no mesmo encarte, é dizer com que personagem o estudante/leitor melhor se identificou na trama e dar exemplos das coisas que as personagens Laura, Joana e Isabel gostam de possuir. Como que vivendo em imaginário "local de compras das personagens", cabe aos estudantes não só se posicionarem no lugar das personagens, mas rememorar seus desejos de consumo. Nessa prática, o que chama a atenção é a importante aprendizagem identitária dos sujeitos a partir do consumo, bem como a filiação aos personagens por meio de tais identidades. Afinal, o estudante deve trabalhar na identificação da personagem que melhor represente a sua relação com o consumo.

Com esse movimento, a protagonização de si busca a identificação do leitor-estudante às histórias exemplares e a articulação a um grupo de ações que agem e fazem agir sobre as ações dos estudantes/personagens, proporcionando a (trans)formação da própria experiência de si.

\section{Julgamento de si}

Para o julgamento de si, o processo de pedagogização do discurso do consumo, tem mobilizado crianças e jovens a julgar seus atos de consumo a partir de critérios, valores e normas que balizam o bem e o mal, o certo e o errado, o normal e o patológico do consumo. Critérios, valores e normas que determinam o julgamento de si e as possíveis ações dos sujeitos sobre si nas práticas de consumo. Ao que parece, a escolarização oferece máquinas ótica para que os estudantes julguem e categorizem suas ações com consumastes ou conscientes, sustentáveis ou não, saudáveis ou não...

$\mathrm{Na}$ Aula Consumismo infantil: característica dos tempos modernos?, por exemplo, o julgamento e a reflexão focam na identificação de situações de consumismo vividas pelos sujeitos escolares ou por pessoas conhecidas e, inversamente, por situações de consumo consciente. A proposta é rememorar as ações de consumo, julgando a si como consumista ou consciente.

O recurso de simuladores para o julgamento de si é utilizado no Plano Sustentabilidade no nosso cotidiano. A proposta de simulação se aplica ao julgamento do consumo de $\mathrm{CO} 2$ - Programa "Iniciativa verde". Por meio de um programa online, os sujeitos escolares avaliam e julgaram seu consumo e o de sua família. Este simulador, porém, apresenta um novo recurso capaz de "solucionar" a relação entre consumo desenfreado e consumo sustentável. Caso as ações de consumo não estejam de acordo com as normas-padrão, o 
simulador oferece como recurso a identificação de quantas árvores cada estudante ou a família deve plantar para "corrigir" seus erros. Como forma de reparar o consumo desviante, $\mathrm{o}$ ato de plantar surge para recompensar a natureza pelos gastos realizados.

O que se percebe na pedagogização do discurso do consumo é que a escolarização tem se preocupado em capacitar os sujeitos escolares para um tipo específico de consumo. Para tanto, ela aciona um conjunto de técnicas capazes de forjá-los e inseri-los em uma sociedade onde o mercado interpela, captura, incita e governa os nossos desejos.

\section{Gerenciamento de si}

Acerca do gerenciamento no campo da educação, Popkewitz (2004, p. 108) afirma que é possível tornar o sujeito "[...] automotivado, autorrealizado e empoderado [...]", por meio de princípios que ordenem e disciplinem sua conduta. Nem esteira desse entendimento, emerge o argumento de que, em um diálogo com o campo discursivo da administração e filiada à perspectiva neoliberal, a escolarização tem se preocupado em capacitar os sujeitos escolares ao "gerenciamento de si" para o livre trânsito na sociedade do capital. Essa categoria, distinta das apresentadas por Larrosa (2008), se materializou no processo de investigação e demarca a ação formadora de auto-administrar suas relações com o consumo.

O gerenciamento de si em relação ao dinheiro entra, por exemplo, na trama do livro No mundo do consumo (GARCIA, 2001). Nele, a mesada ${ }^{10}$ vira tema de debate na aula da professora Sandra. Durante o enredo, a professora explica aos alunos que cada família administra o seu dinheiro a seu modo. Umas dão mesada, outras não. Aos que recebem e aos que receberão mesada, ela explica que "[...] como ninguém tem a lâmpada de Aladim para satisfazer todos os desejos, é bom [...]" (GARCIA, 2001, p. 24) seguir os três passos apresentados abaixo (Figura 4):

${ }^{10}$ Segundo o enredo do livro No mundo do consumo: a administração das necessidades e dos desejos (GARCIA, 2001, p. 10) "[...] a mesada é uma quantia em dinheiro que uma pessoa recebe para gastar em seu próprio benefício [...]". 
Figura 4 - Entendendo o consumo

- Como não é possível consultar tudo e como ninguém tem a lâmpada de Aladim para satisfazer todos os desejos, é bom:

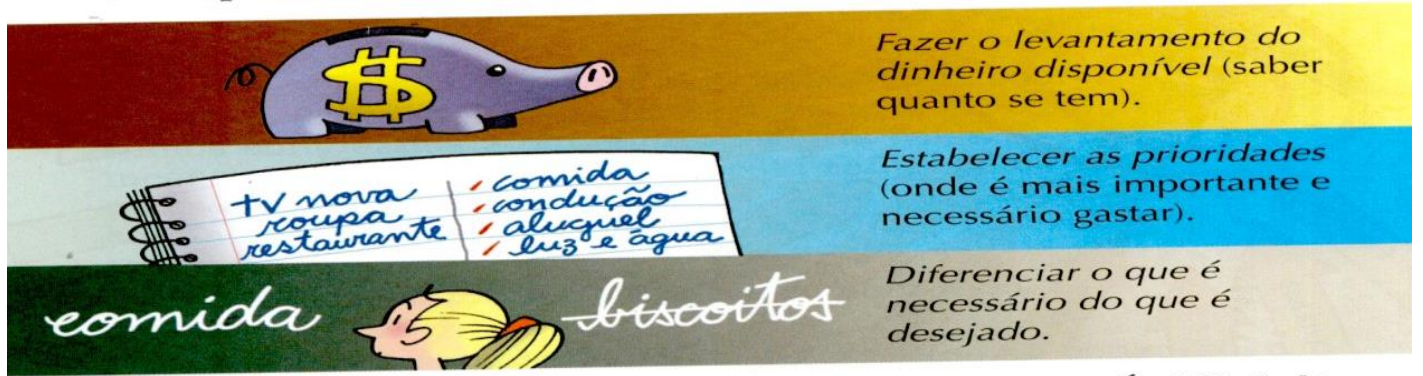

- O dinheiro entra e sai da vida das pessoas. É difícil de entrar e muito fácil de sair. Por isso é preciso planejar as compras, os gastos e a poupança.

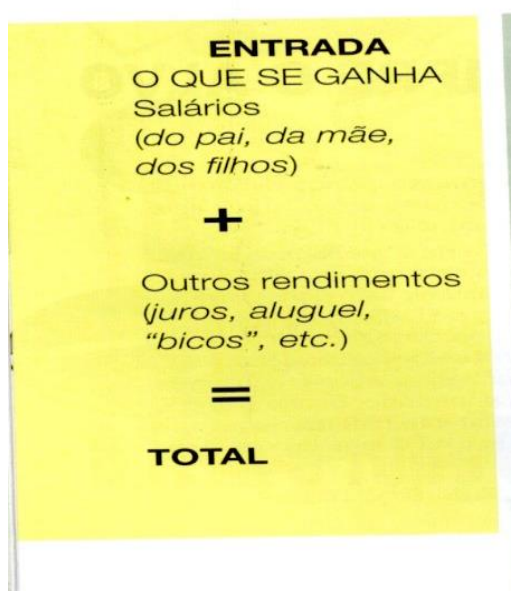

\begin{tabular}{|c|c|}
\hline \multicolumn{2}{|c|}{$\begin{array}{c}\text { SAÍDA } \\
O \text { QUE SE GASTA }\end{array}$} \\
\hline ạlimentação + & + \\
\hline àluguel & + \\
\hline educação & + \\
\hline roupas & + \\
\hline impostos & + \\
\hline transporte & + \\
\hline prestação & + \\
\hline remédios & + \\
\hline doações & + \\
\hline lazer, etc. & $=$ \\
\hline TOTAL & \\
\hline & 34 \\
\hline
\end{tabular}

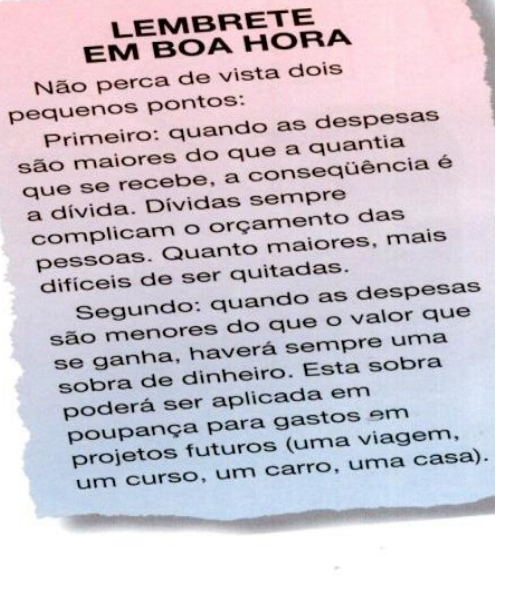

Fonte: Garcia (2001).

Caso as práticas do consumo se estabeleçam de forma desenfreada e os sujeitos escolares notem-se sem dinheiro, o livro No mundo do consumo: a administração das necessidades e dos desejos (GARCIA, 2001) ensina os caminhos possíveis para a solução desse "problema" (Figura 5).

\section{Figura 5 - Se não há dinheiro}




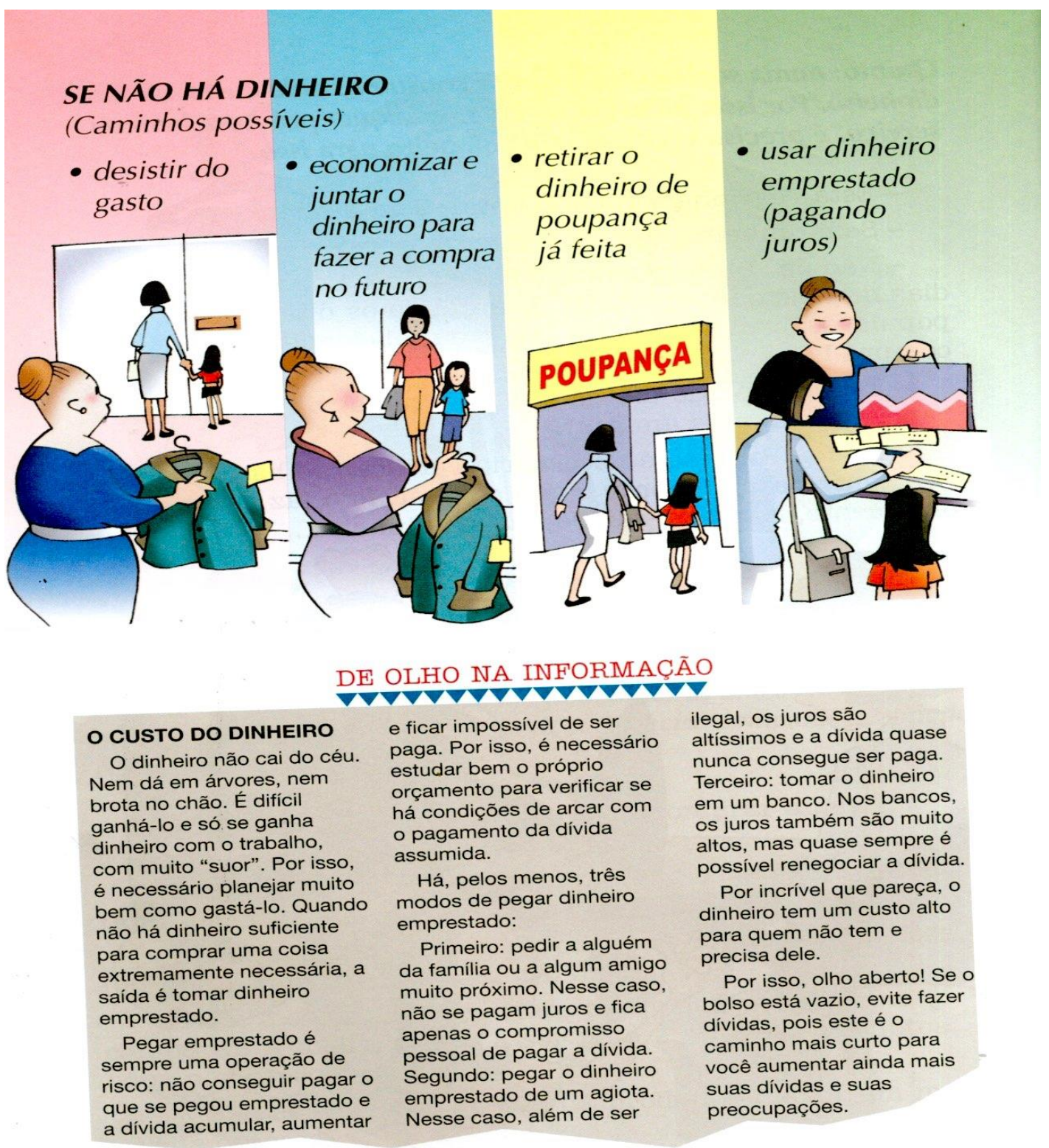

Fonte: Garcia (2001).

40

Em relação à técnica de "gerenciamento de si", o processo de escolarização tem instituído um conjunto de práticas que estabelecem orientações reflexivas do pensamento, por meio das quais os sujeitos escolares interiorizam os critérios normativos sistematizados pela escolarização do consumo, não para deixar de consumir, mas para consumir de acordo com um campo de critérios prescritos.

\section{Considerações finais}

A vontade de verdade dos profissionais do campo da educação de

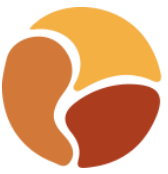


educar para o consumo não é recente. Já em 1986 foi aplicado, em escolas públicas do Rio Grande do Sul, um plano experimental de Educação do Consumidor (BRASIL, 1990b). Em âmbito nacional, o Ministério da Educação, por meio da Secretaria Nacional de Educação Básica, reuniu, na década de 1990, especialistas em Educação do Consumidor com o objetivo de estudar a viabilidade da inclusão da referida temática nos currículos escolares de Educação Básica.

A partir de então, o discurso do consumo vem passando por um processo de recontextualização, ou seja, a transferência de textos de outros campos do saber para o campo da educação (BERSTEIN, 2003). Processo em que o discurso do consumo foi inserido nas práticas discursivas escolares por meio da reescrita, do reposicionamento, da transcrição e da refocalização. Nessa recontextualização, a que nomeamos neste artigo de pedagogização, a educação selecionou, de tal discurso o que considerou pertinente à sua função social e de interesse da sociedade e o escolarizou, o didatizou, o qualificou de acordo com sua gramática discursiva.

Dentro dessa racionalidade, o corpus analisado deu visibilidade a um emaranhado de textos enunciadores do discurso do consumo, onde regras são acionadas para que a presença do consumo seja autorizada e materializada no campo da educação. Por meio da análise dessas regras é possível afirmar que o discurso do consumo foi pedagogizado pelas práticas discursivas escolares, isso porque:

a) o processo de escolarização aciona um conjunto de relações conceituais entre diferentes campos de saber para munir o sujeito escolar de informações que o apropriam do discurso do consumo;

b) considerado, reconhecido, delimitado, descrito, analisado, (re)interpretado, transcrito, (r)econtextualizado e reescrito, esse discurso passou a fazer parte dos campos de saberes eleitos pela escolarização;

c) temas como "a racionalidade e administração dos desejos de consumo", "consumir é criar uma identidade", "consumir é usar os direi- tos de cidadão", "atos e procedimentos de compras", "o consumo e o bem-estar social", "o consumo consciente", "o consumo saudável", entre outros, passaram a fazer parte das lições escolares;

d) os corpos, a vida social e afetiva, a conduta, o comportamento e a alma dos estudantes passaram a ser relacionados ao discurso do consumo;

e) especialistas do campo da educação e os autores de livros o situam como pertencente aos saberes da educação;

f) o Ministério da Educação, a mídia, os livros paradidáticos e manuais de professores, os sites especializados, o Ministério Público e a Promotoria do 
Consumidor reverberam e promovem a dispersão dos enunciados do consumo no processo de escolarização;

g) promove tecnologias que incitam, induzem, desviam, ampliam, limitam, coagem, balizam as ações dos sujeitos escolares em relação ao consumo;

Em outras palavras, o consumo que dantes transitava no processo de escolarização em materiais escolares, nos artefatos midiáticos, nos relatos infantis, em tempos presentes, se materializou nas práticas discursivas escolares brasileiras e passou a fazer parte dos saberes do campo da educação. Assim sendo, já se pode falar em produção pedagógica do sujeito consumidor nas práticas discursivas escolares.

\section{REFERÊNCIAS}

ARAÚJO, Regina Magna Bonifácio de. A escola e o desenvolvimento do pensamento econômico em crianças: uma proposta de avaliação e intervenção. In: REUNIÃO ANUAL DA ANPED, 31, 2008, Caxambu. Anais... Rio de Janeiro: ANPEd, 2008.

AROEIRA, Maria Luísa C.; SOARES, Maria Inês B.; MENDES, Rosa Emília A. Didática de pré-escola: vida criança: brincar e aprender. São Paulo: FTD, 1996.

AVELINO, Nildo. Governamentalidade e anarqueologia em Michel Foucault. Revista Brasileira de Ciências Sociais, São Paulo, v. 25, n.74, p. 139-195, out. 2010.

BAUMAN, Zygmunt. Modernidade líquida. Rio de Janeiro: Jorge Zahar, 2001.

BAUMAN, Zygmunt. Vida para consumo: a transformação das pessoas em mercadoria. Rio de Janeiro: Zahar, 2008.

BERNSTEIN, Basil. A pedagogização do conhecimento: estudos sobre recontextualização. Cadernos de Pesquisa, São Paulo, n. 120, p. 75-110, nov. 2003.

BRASIL. Ministério da Educação. Secretaria de Educação Fundamental. Parâmetros curriculares nacionais: introdução aos parâmetros curriculares nacionais. Brasília: MEC, 1997.

BRASIL. Ministério da Educação. Consumo sustentável: manual de educação. Brasília: MEC, 2005a.

BRASIL. Ministério da Educação. De onde vêm os produtos que consumimos?: aula. Brasília, DF: MEC, 2009a. Disponível em:

http://portaldoprofessor.mec.gov.br/fichaTecnicaAula.html?aula=10031. Acesso em: 21 mar. 2014.

BRASIL. Ministério da Educação. Publicidade: uma fábrica de desejos: aula. Brasília, DF: MEC, 2009b. Disponível em:

http://portaldoprofessor.mec.gov.br/fichaTecnicaAula.html?aula=7737. Acesso em: 21 mar. 2014. 
BRASIL. Ministério da Educação. Sustentabilidade no nosso cotidiano: aula. Brasília, DF: MEC, 2009c. Disponível em:

http://portaldoprofessor.mec.gov.br/fichaTecnicaAula.html?aula=1864. Acesso em: 21 mar. 2014.

BRASIL. Ministério da Educação. Comer, comer para poder crescer: aula. Brasília, DF: MEC, 2010b. Disponível em:

http://portaldoprofessor.mec.gov.br/fichaTecnicaAula.html?aula=20840. Acesso em: 21 mar. 2014.

BRASIL. Ministério da Educação. Dialogando com o lixo, preservação do ambiente: aula. Brasília, DF: MEC, 2010c. Disponível em:

http://portaldoprofessor.mec.gov.br/fichaTecnicaAula.html?aula=10031. Acesso em: 21 mar. 2014.

BRASIL. Ministério da Educação. Educação básica: portal do professor. Brasília, DF: MEC, c2010d. Disponível em:

http://gestao2010.mec.gov.br/o_que_foi_feito/program_84.php. Acesso em: 21 mar. 2014.

BRASIL. Ministério da Educação. Saúde é o que interessa: de olho na alimentação e na atividade física: aula. Brasília, DF: MEC, 2010e. Disponível em:

http://portaldoprofessor.mec.gov.br/fichaTecnicaAula.html?aula=22653. Acesso em: 21 mar. 2014.

BRASIL. Ministério da Educação. Consumismo infantil: característica dos tempos modernos?: aula. Brasília, DF: MEC, 2011a. Disponível em:

http://portaldoprofessor.mec.gov.br/fichaTecnicaAula.html?aula=29465. Acesso em: 21 mar. 2014.

BRASIL. Ministério da Educação. Moda e consumo infantil - UCA: aula. Brasília, DF: MEC, 2011b. Disponível em:

http://portaldoprofessor.mec.gov.br/fichaTecnicaAula.html?aula=32196. Acesso em: 21 mar. 2014.

BRASIL. Ministério da Educação. Aprendendo com a propaganda: aula. Brasília, DF: MEC, 2012. Disponível em:

http://portaldoprofessor.mec.gov.br/fichaTecnicaAula.html?aula=41366. Acesso em: 21 mar. 2014.

BRASIL. Ministério da Educação. Diretrizes curriculares nacionais gerais da educação básica. Brasília, DF: MEC, 2013.

CANCLINI, Néstor Garcia. Consumidores e cidadãos: conflitos multiculturais da globalização. 6. ed. Rio Janeiro: UFRJ, 2006.

COELHO, Maria de Lourdes. Consumo e espaços pedagógicos. 2. ed. São Paulo: Cortez, 2002.

COSTA, Marisa Vorraber. (Org.). A educação na cultura da mídia e consumo. Rio de Janeiro: Lamparina, 2009.

COSTA, Marisa Vorraber; MOMO, Mariangela. Sobre a "conveniência" da escola. Revista Brasileira de Educação, Rio de Janeiro, v. 14, n. 42, p. 521-533, dez. 2009.

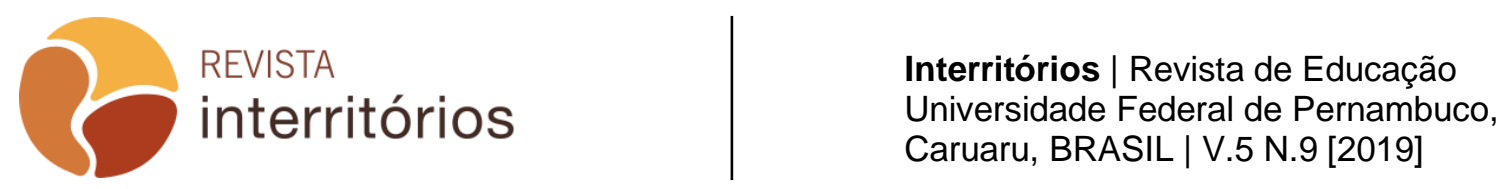


CUNHA, Beatriz Monteiro da. Os heróis e o consumo consciente. São Paulo: Evoluir, 2011.

DELEUZE, Gilles. Foucault. Lisboa: Edições 70, 1986.

FEATHERSTONE, Mike. Cultura de consumo e pós-modernismo. São Paulo: Studio Nobel, 1995.

FISCHER, Rosa Maria Bueno. Foucault e a análise do discurso em educação.

Cadernos de Pesquisa, São Paulo, v. 114, p. 197-223, 2001.

FLOR, Douglas Moacir. A convocação para o consumo nas pedagogias culturais circuitos e teias do complexo Rebelde. 2007. Dissertação (Mestrado em Educação). Canoas: Centro de Educação da ULBRA. 2007.

FORQUIN, Jean-Claude. Escola e cultura: as bases sociais epistemológicas do conhecimento escolar. Porto Alegre: Artes Médicas, 1993.

FOUCAULT, Michael. Microfísica do poder. 25. ed. São Paulo: Graal, 2008a.

FOUCAULT, Michael. Ordem do discurso. 16. ed. São Paulo: Loyola, 2008b.

FOUCAULT, Michael.Arqueologia do saber. 7. ed. Rio de Janeiro: Forense Universitária, 2009.

GARCIA, Edson Gabriel. No mundo do consumo: a administração das necessidades e dos desejos. São Paulo: FTD, 2001.

IGNÁCIO, Patrícia. Aprendendo a consumir com "Três Espiãs Demais". (Dissertação de Mestrado). Canoas: Centro de Educação da ULBRA. 2007.

JAF, Ivan; PALMA, Daniela. O preço do consumo. São Paulo: Ática, 2008.

KLEIN, Naomi. Sem logo: a tirania das marcas em um planeta vendido. 7. ed. Rio de Janeiro: Record, 2009.

LARROSA, Jorge. A novela pedagógica e a pedagogização da novela. In:

Pedagogia profana: danças, piruetas e mascaradas. 5. ed. Belo Horizonte: Autêntica, 2013. p. 117-138.

LIBÂNEO, José Carlos. Pedagogia e pedagogos: inquietações e buscas. Educar, Curitiba, n. 17, p. 153-176, 2001.

LIPOVETSKY, Gilles. A felicidade paradoxal: ensaio sobre a sociedade de hiperconsumo. São Paulo: Companhia das Letras, 2007.

MCLAREN, Peter. Multiculturalismo crítico. São Paulo: Cortez, 1997.

MERLI. O camelo, o burro e a água. São Paulo: Melhoramentos, 2010.

MOMO, Mariangela. Mídia e consumo na produção de uma infância pós-moderna que vai à escola (Tese de Doutorado). Porto Alegre: Faculdade de Educação a UFRGS. 2007. 
MOMO, Mariangela; COSTA, Marisa Vorraber. Crianças escolares do século XXI: para se pensar uma infância pós-moderna. Cadernos de Pesquisa, São Paulo, v. 40, n. 141, p. 965- 991, set./dez. 2010.

PARAÍSO, Marlucy Alves. Metodologias de pesquisa pós-críticas em educação e currículo: trajetórias, pressupostos, procedimentos e estratégias analíticas. In: MEYER, Dagmar Estermann; PARAÍSO, Marlucy Alves (Orgs.). Metodologias de pesquisas pós-críticas em educação. Belo Horizonte: Mazza, 2012.

PERNAMBUCO. Ministério Público. Promotoria de Justiça e Defesa do Consumidor. Direito do consumidor e publicidade enganosa: a escolha certa, brincando e aprendendo a ser um consumidor legal. Recife: Promotoria de Justiça e Defesa do Consumidor, 2010.

POPKEWITZ, Thomas S. História do currículo, regulação social e poder. In: SILVA, Tomaz Tadeu da (Org.). O sujeito da educação: estudos foucaultianos. 6. ed. Petrópolis: Vozes, 2008. p. 173-210.

ROSE, Nikolas. Governando a alma: a formação do eu privado. In: SILVA, Tomaz Tadeu da (Org.). Liberdades reguladas. Rio de Janeiro: Vozes, 1998. p. 30-45.

SARFATI, Georges-Élia. Princípios da análise do discurso. São Paulo: Ática, 2010.

SARLO, Beatriz. Cenas da vida pós-moderna: intelectuais, arte e videocultura na Argentina. 4. ed. Rio de Janeiro: UFRJ, 2006.

SCHOR, Juliet B. Nascidos para comprar: uma leitura essencial para orientarmos nossas crianças na era do consumismo. São Paulo: Gente, 2009.

TAVARES, Victor. Carlitos contra o consumo. São Paulo: Noovha América, 2011.

VALENÇA, Marcos Moraes. Escola: indústria cultural ou espaço do prazer cultural? (Dissertação de Mestrado). Canoas: Centro de Educação e UFPE. 2002.

VARELA, Julia. O estatuto do saber pedagógico. In: SILVA, Tomaz Tadeu da (Org.). 0 sujeito da educação: estudos foucaultianos. 4. ed. Petrópolis: Vozes, 2000. p. 87-96.

VEYNE, Paul Marie. Como se escreve a história. Foucault revoluciona a história. 4. ed. Brasília: UnB, 2008.

WORTMANN, Maria Lúcia Castagena. Análises culturais: um modo de lidar com histórias que interessam à educação. In: COSTA, Maria Vorraber (Org.). Caminhos investigativos II: outros modos de pensar e fazer pesquisa em educação. Rio de Janeiro: DP\&A, 2007. p. 73-92. 